J.Soc. Csmet. Chem. Jpn.

$\left[\begin{array}{ll}\text { 報 } \\ 26 & \text { (4) } 269-279 \text { (1993) }\end{array}\right]$

\title{
皮膚表面状態に及ぼす気流の影響
}

\author{
梶原理恵 $\dagger^{1}$ ，新井清一 $\dagger^{1}$ ，福田吉宏 $\dagger^{1} ，$ 井川正治 $\dagger^{2}$ \\ 鐘紡株式会社化粧品研究所 $\dagger^{1}$ \\ 日本体育大学健康管理学研究室 ${ }^{2}$
}

\section{Effects of Wind on Skin Surface}

\author{
Rie Kajiwara $\dagger^{1}$, Seiichi Arai $\dagger^{1}$, Yoshihiro Fukuda $\dagger^{1}$ and Syoji Igawa $\dagger^{2}$ \\ Kanebo Ltd., Cosmetics Laboratory. $\dagger^{1}$ \\ Nippon College of Physical Education. $\dagger^{2}$
}

\begin{abstract}
The relation between the wind and the skin physiology was examined as part of the research concerning the environment and the physiology. As a constant wind was exposed to the face, the change of the skin physiological parameters were examined.

Subjects consisted of 8 healthy men $(24-44 \mathrm{yr})$. Subject's face were exposed to various wind (air velocity $0,1.0,2.0,3.0,4.0 \mathrm{~m} / \mathrm{sec}$ ) at environmental condition of $25^{\circ} \mathrm{C}$ and $60 \% \mathrm{R} . \mathrm{H}$. Also, wind $(2.0 \mathrm{~m} / \mathrm{s})$ was exposed at the different air temperature, i.e., 15, 25 and $30^{\circ} \mathrm{C}$. Measurement items were skin temperature at forehead, cheek, nose and chin, hydration state of cheek, replacement sebum level of forehead, observation of skin surface and psychological effects.

The skin temperature has decreased intentionally by the wind exposure. The hydration state has also decreased by wind exposure. However, the relation was not admitted in level of air velocity and the decrease of hydration state. The replacement sebum level was showed low value by wind exposure. Morever, the correlation between skin temperature and psychological response (comfort sensation and thermal sensation) was found.

This study showed that wind influenced on the skin temperature and the other skin physiological factors, i.e. the various skin functions were discerned by wind, and that wind influenced on the comfort and thermal sensations.
\end{abstract}

\section{1. 緒言}

我々を取り巻く気象条件は, 気温, 湿度, 気流 という3つの要素から成り立ち, この要素が組み 合わされ様々な環境を形成している。また，冷暖

$\dagger^{1} \quad$ 个250 神奈川県小田原市寿町 5-3-28; 5-3-28, Kotobuki-cho, Odawara-shi, Kanagawa, 250 Japan

$\uparrow^{2} \quad$ T158 東京都世田谷区深沢 7-1-1；7-1-1, Fukazawa, Setagaya-ku, Tokyo 158 Japan
房の普及に伴い人工的な気温調節が行われ, 空調 による気流が発生し, 室内に打いても複雑な環境 が形成されるようになった。そしてこの環境と常 に接している皮膚は，様々な影響を及ぼされてい る。

例えば，気温上昇に伴う皮脂量の増加，気温や 湿度上昇に伴ら角層水分含有量の増加, また, 水 分蒸散量, 発汗等への影響など，気温や湿度によ る皮膚生理への影響について，これまでに多くの 報告がなされてきだ〜4。しかし，気流に拈いて 
は, 生理学分野で，皮膚温や代謝量等の生理的反 応についての検討が行われているものの市,6)，斗 膚生理との関係については，報告されている例が ない。
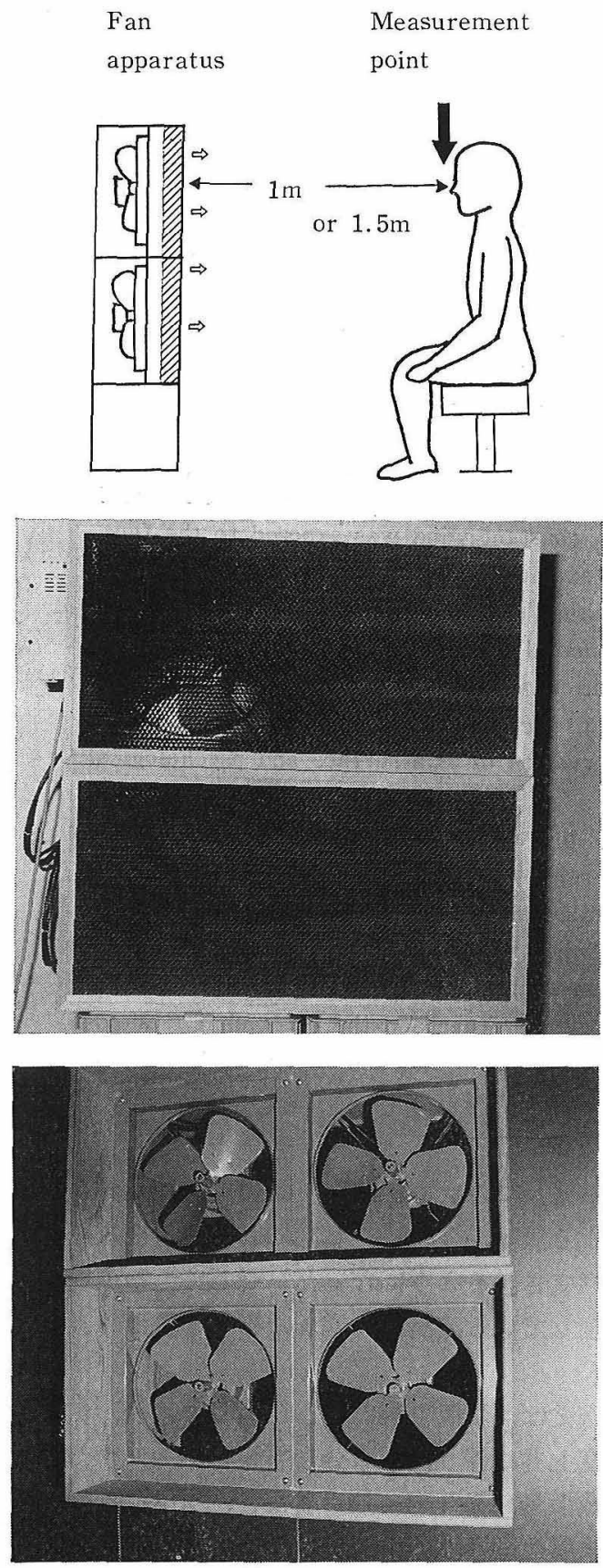

Fig.-1 Plan of air velocity
そこで，気流と皮膚生理との関係を明確にすべ く検討を行った。

\section{2. 実験}

\section{1 気流発生装置}

早川 $\|^{7)}$ らの気流発生装置を参考にして, $1.2 \mathrm{~cm}$ 厚ベニヤ合板，換気扇 4 台及びペーパーハニカム 整流板を用いて Fig.-1 に示す気流発生装置を作 成した。

装置のサイズは H0.9m×W0. $8 \mathrm{~m} \times \mathrm{D} 0.6 \mathrm{~m}$ で， 気流速度は换気扇への供給電圧をスライダックで 調節することにより制御した。

\section{2 被験者}

被験者は24 44歳（平均年齡32歳）の健常成人 男子 8 名を対象とした。

\section{3 測定条件}

気流発生装置は被験者の顔面から気流吹き出乙 口までの距離が 1.0 及び $1.5 \mathrm{~m}$ の位置に設置し， 顔面での気流速度を気流条件として，Table-1に 示した環境条件で測定を行った。すなわち，異な る気流条件での影讋を検討するため，気温 $25^{\circ} \mathrm{C}$, 湿度 $60 \%$ に設定した人工気候室に就いて，0，1.0， $2.0 ， 3.0 ， 4.0 \mathrm{~m} / \mathrm{s}$ の 5 段階の気流を暴露した。 また，異なる気温環境条件下での気流の影響を検 討するため，気温 $15 ， 25 ， 30^{\circ} \mathrm{C}$ の 3 段階に执い て, 湿度は $60 \%$, 気流 $0 \mathrm{~m} / \mathrm{s}, 2.0 \mathrm{~m} / \mathrm{s}$ を暴露し 測定を行った。な秥，気流は人工気候室において 被験者を30分間安静にした後，60分間暴露した。

Table-1 Experimental conditions

\begin{tabular}{lll}
\hline & Experiment 1 & Experiment 2 \\
\hline $\begin{array}{lll}\text { Air temperature } \\
\text { (Ta) }\end{array}$ & $25^{\circ} \mathrm{C}$ & $15,25,30^{\circ} \mathrm{C}$ \\
Relative humidity & & \\
(RH) & $60 \%$ & $60 \%$ \\
Air velocity & $0,1.0,2.0,3.0$, & $0,2.0 \mathrm{~m} / \mathrm{s}$ \\
& $4.0 \mathrm{~m} / \mathrm{s}$ & \\
\hline
\end{tabular}

\section{4 測定項目}

測定項目は，皮膚表面温度，角質水分含有量， 回復皮脂量及び皮膚状態観察とし，いずれにおい ても被験者は 8 名とした。 


\section{4 .1 皮膚表面温度}

皮膚表面温度はサーモトレーサ 6T66（日本電 気三栄(秼) を用い, 額, 煩, 鼻, 顎部の 4 部位に ついて測定した。測定は, 気流暴露開始直前, 気 流暴露 30,60 分後に計 3 回実施した。

\section{4 .2 角層水分含有量}

角層水分含有量は $3.5 \mathrm{MHz}$ 高周波伝導度測定装 置 (中心電極 $1 \mathrm{~mm}$ 周辺電極 $6 \mathrm{~mm}$ IBS 社) で煩 部を測定した。測定は皮膚表面温度と同様, 気流 暴露開始直前, 気流暴露30，60分後に実施した。

\section{4 .3 回復皮脂量}

ガラス製カップ $(\phi=2.1 \mathrm{~cm})$ を額にあて，アセ トンにより皮表脂質を抽出し，スクワレンをマー カーとしてガスクロマトグラフィーで定量した。

気流暴露開始直前にアセトンで一旦皮脂を抽出除 去し, 気流暴露60分後に同一部位で再び抽出した ものを回復皮脂量とした。

\section{4 .4 皮膚状態観察}

アセトンにより皮脂抽出した皮膚部をビデオマ イクロスコープ（ウィルソン社）で拡大観察（X 30）した。アセトン抽出により発生した鱗首及び 落佰の状態から Table-2 に示すよらにスコアを つけ, 気流暴露60分後の皮膚状態の回復を検討し た。

\section{5 アンケート調査}

気流の心理面への影響を検討するべく Table3 に示した項目 ${ }^{7)}$,8) でアンケート調査を行った。 アンケートは気流暴露 60 分後に調査を行った。温 熱条件を総合的に評価する為に「快適感」, 気流に よる暑さ寒さの感覚「温冷感」, 乾湿の感覚「乾湿 感」,の 3 項目それぞれ 7 段階評定尺度をとった。

\section{3. 結果}

\section{1 皮膚表面温度}

異なった気流速度に打ける皮膚表面温度の測定 結果を Table-4 に示した。 $0 \mathrm{~m} / \mathrm{s}$ では, 皮膚表 面温度は60分後に拈いてもほぼ一定值を保ってい るのに対し, 気流暴露すると60分後には有意に低 下が認められた（ $\mathrm{p}<0.01)$ 。皮膚表面温度の低下 は送風直後より認められたが，暴露30分から60分 後に打ける変化は小さかった。例えば，気流 4.0
Table-2 The clinical grade by the naked eye

\begin{tabular}{cl}
\hline grade & \multicolumn{1}{c}{ feature } \\
\hline 1 & Surface smooth, no peeling \\
2 & Slight dryness with small scales \\
3 & Moderate dryness with numerous scales \\
4 & Extreme dryness with prominent scales \\
\hline
\end{tabular}

Table-3 Category scale of three kinds of thermal sensation

\begin{tabular}{|c|c|}
\hline Comfort sensation & 快適感 \\
\hline-3 very uncomfortable & 非常に不快 \\
\hline-2 uncomfortable & 不快 \\
\hline-1 slightly uncomfortable & やや不快 \\
\hline 0 neutral & どちらでもない \\
\hline 1 slightly comfortable & やや快適 \\
\hline 2 comfortable & 快適 \\
\hline 3 very comfortable & 非常に快適 \\
\hline Temperature sensation & 温冷感 \\
\hline-3 very cold & 寒い: \\
\hline$-2 \operatorname{cool}$ & 涼しい \\
\hline-1 slightly cool & やや涼しい \\
\hline 0 neutral & どちらでもない \\
\hline 1 slightly warm & やや䁔か、い \\
\hline 2 warm & 暖かい \\
\hline 3 hot & 暑い \\
\hline Wetness sensation & 乾湿感 \\
\hline-3 very dry & 非常に乾いている \\
\hline-2 dry & 乾いている \\
\hline-1 slightly dry & やや乾いている \\
\hline 0 neutral & ぞちらでもない \\
\hline 1 slightly wet & やや湿っている \\
\hline 2 wet & 湿っている \\
\hline 3 very wet & 非常に湿っている \\
\hline
\end{tabular}

$\mathrm{m} / \mathrm{s}$ の条件で，煩部に抢ける30分暴露では， 3.7 ${ }^{\circ} \mathrm{C}$ の低下が認められたのに対し，60分後におい ては $4.0^{\circ} \mathrm{C}$ 低下であった。他の気流速度に打い ても， 2 から $4^{\circ} \mathrm{C}$ の低下があり, また, 額, 鼻, 顎に扣いても煩と同様の挙動であった。

次に，異なった気温条件に抢汀る皮膚表面温度 の測定結果を Table-5 に示した。各気温条件下 での皮膚表面温度への影響は, 低温環境になるほ ぞ低值を示した。気流暴露では, どの気温条件で も皮膚表面温度の低下があり，特に $15^{\circ} \mathrm{C}$ におい 
Table-4 The effects of air velocity on skin temperature $\left({ }^{\circ} \mathrm{C}\right)$, the temperature of the air was set of $25^{\circ} \mathrm{C}$

\begin{tabular}{ccccccc}
\hline \multirow{2}{*}{ site } & & \multicolumn{2}{c}{ air velocity $(\mathrm{m} / \mathrm{s})$} \\
\multirow{3}{*}{ forehead } & time & 0 & 1.0 & 2.0 & 3.0 & 4.0 \\
& before & $33.6 \pm 0.31^{* 1}$ & $33.0 \pm 0.36$ & $33.3 \pm 0.90$ & $33.1 \pm 0.32$ & $33.3 \pm 0.60$ \\
& 30min. & $33.7 \pm 0.44$ & $30.7 \pm 0.98$ & $30.5 \pm 1.15$ & $30.4 \pm 0.24$ & $29.8 \pm 0.99$ \\
& 60min. & $33.6 \pm 0.38$ & $31.0 \pm 0.62$ & $30.7 \pm 1.50$ & $30.3 \pm 0.42$ & $29.7 \pm 0.83$ \\
\hline \multirow{3}{*}{ cheek } & before & $33.5 \pm 0.58$ & $32.8 \pm 0.88$ & $33.6 \pm 0.41$ & $32.9 \pm 0.73$ & $32.9 \pm 0.90$ \\
& 30min. & $33.6 \pm 0.46$ & $30.7 \pm 1.18$ & $31.5 \pm 1.14$ & $30.0 \pm 1.32$ & $29.2 \pm 1.57$ \\
& 60min. & $33.5 \pm 0.64$ & $30.3 \pm 1.26$ & $31.5 \pm 0.99$ & $29.6 \pm 1.43$ & $28.9 \pm 1.52$ \\
\hline \multirow{3}{*}{ nose } & before & $33.3 \pm 0.33$ & $32.9 \pm 0.47$ & $33.4 \pm 0.39$ & $33.2 \pm 0.34$ & $33.2 \pm 0.91$ \\
& 30min. & $33.3 \pm 0.64$ & $30.8 \pm 1.17$ & $31.1 \pm 1.28$ & $30.3 \pm 1.18$ & $28.9 \pm 2.29$ \\
& 60min. & $32.8 \pm 1.11$ & $29.7 \pm 1.40$ & $30.2 \pm 2.61$ & $29.3 \pm 2.20$ & $28.0 \pm 2.76$ \\
\hline \multirow{3}{*}{ chin } & before & $33.3 \pm 0.50$ & $32.9 \pm 0.42$ & $33.2 \pm 0.36$ & $33.1 \pm 0.37$ & $32.9 \pm 0.63$ \\
& 30min. & $33.4 \pm 0.60$ & $30.3 \pm 0.69$ & $30.7 \pm 1.06$ & $29.9 \pm 0.78$ & $28.8 \pm 1.01$ \\
& 60min. & $33.4 \pm 0.51$ & $29.9 \pm 1.12$ & $30.6 \pm 1.19$ & $29.6 \pm 0.88$ & $28.4 \pm 0.98$ \\
\hline
\end{tabular}

Statistical analysis was performed for each combination of two values*2

[forehead 60min.] : $0 \mathrm{~m} / \mathrm{s} \gg 1.0 \mathrm{~m} / \mathrm{s} \fallingdotseq 2.0 \mathrm{~m} / \mathrm{s} \fallingdotseq 3.0 \mathrm{~m} / \mathrm{s}>4.0 \mathrm{~m} / \mathrm{s}$

[cheek $60 \mathrm{~min}$.] : $0 \mathrm{~m} / \mathrm{s} \gg 2.0 \mathrm{~m} / \mathrm{s} \gg 1.0 \mathrm{~m} / \mathrm{s} \fallingdotseq 3.0 \mathrm{~m} / \mathrm{s} \fallingdotseq 4.0 \mathrm{~m} / \mathrm{s}$

[nose $60 \mathrm{~min}$.] : $0 \mathrm{~m} / \mathrm{s} \gg 2.0 \mathrm{~m} / \mathrm{s} \fallingdotseq 1.0 \mathrm{~m} / \mathrm{s} \fallingdotseq 3.0 \mathrm{~m} / \mathrm{s} \fallingdotseq 4.0 \mathrm{~m} / \mathrm{s}$

[chin $60 \mathrm{~min}$.] : $0 \mathrm{~m} / \mathrm{s} \gg 2.0 \mathrm{~m} / \mathrm{s} \fallingdotseq 1.0 \mathrm{~m} / \mathrm{s} \fallingdotseq 3.0 \mathrm{~m} / \mathrm{s} \fallingdotseq 4.0 \mathrm{~m} / \mathrm{s}$

*1: Mean \pm S.D.

$*_{2}:$ t-test $\sqcup \gg: \mathrm{P}<0.01,>: \mathrm{P}<0.05, \fallingdotseq$ not significant

Table-5 The effects of air velocity and air temperature on skin temperature $\left({ }^{\circ} \mathrm{C}\right)$

\begin{tabular}{|c|c|c|c|c|c|c|c|}
\hline \multirow[b]{2}{*}{ site } & \multirow[b]{2}{*}{ time } & \multicolumn{2}{|c|}{$15^{\circ} \mathrm{C}$} & \multicolumn{2}{|c|}{$25^{\circ} \mathrm{C}$} & \multicolumn{2}{|c|}{$30^{\circ} \mathrm{C}$} \\
\hline & & $0 \mathrm{~m} / \mathrm{s}$ & $2.0 \mathrm{~m} / \mathrm{s}$ & $0 \mathrm{~m} / \mathrm{s}$ & $2.0 \mathrm{~m} / \mathrm{s}$ & $0 \mathrm{~m} / \mathrm{s}$ & $2.0 \mathrm{~m} / \mathrm{s}$ \\
\hline \multirow{3}{*}{ forehead } & before & $30.5 \pm 0.75^{* 1}$ & $30.5 \pm 0.61$ & $33.5 \pm 0.34$ & $33.5 \pm 0.26$ & $34.6 \pm 0.22$ & $34.9 \pm 0.39$ \\
\hline & $30 \mathrm{~min}$. & $29.8 \pm 0.46$ & $25.8 \pm 0.65$ & $33.5 \pm 0.29$ & $30.9 \pm 0.43$ & $34.9 \pm 0.18$ & $33.7 \pm 0.27$ \\
\hline & $60 \mathrm{~min}$. & $29.8 \pm 0.77$ & $25.6 \pm 0.72$ & $33.4 \pm 0.37$ & $31.4 \pm 0.63$ & $35.0 \pm 0.28$ & $33.7 \pm 0.29$ \\
\hline \multirow{3}{*}{ cheek } & before & $30.2 \pm 1.24$ & $30.2 \pm 1.21$ & $33.8 \pm 0.55$ & $33.3 \pm 1.03$ & $34.7 \pm 0.41$ & $34.9 \pm 0.48$ \\
\hline & $30 \mathrm{~min}$. & $29.2 \pm 1.31$ & $25.3 \pm 1.39$ & $33.8 \pm 0.56$ & $31.2 \pm 1.65$ & $35.0 \pm 0.38$ & $34.1 \pm 0.44$ \\
\hline & $60 \mathrm{~min}$. & $28.8 \pm 1.58$ & $24.3 \pm 1.29$ & $33.7 \pm 0.61$ & $31.3 \pm 1.54$ & $35.1 \pm 0.34$ & $33.9 \pm 0.63$ \\
\hline \multirow{3}{*}{ nose } & before & $29.6 \pm 1.22$ & $30.1 \pm 0.57$ & $33.3 \pm 0.35$ & $33.3 \pm 0.39$ & $34.7 \pm 0.18$ & $35.0 \pm 0.22$ \\
\hline & $30 \mathrm{~min}$. & $25: 3 \pm 2.86$ & $21.5 \pm 2.76$ & $33.2 \pm 0.67$ & $31.4 \pm 1.11$ & $34.7 \pm 0.24$ & $34.3 \pm 0.43$ \\
\hline & $60 \mathrm{~min}$. & $24.6 \pm 3.33$ & $20.0 \pm 2.76$ & $32.8 \pm 1.18$ & $30.8 \pm 2.34$ & $34.9 \pm 0.11$ & $34.2 \pm 0.30$ \\
\hline \multirow{3}{*}{ chin } & before & $30.3 \pm 0.65$ & $30.5 \pm 0.68$ & $33.4 \pm 0.44$ & $33.2 \pm 0.37$ & $34.7 \pm 0.23$ & $34.9 \pm 0.16$ \\
\hline & $30 \mathrm{~min}$. & $29.1 \pm 0.80$ & $24.0 \pm 1.07$ & $33.5 \pm 0.60$ & $31.0 \pm 0.90$ & $34.9 \pm 0.20$ & $33.5 \pm 0.21$ \\
\hline & $60 \mathrm{~min}$. & $28.8 \pm 1.12$ & $23.6 \pm 1.18$ & $33.4 \pm 0.53$ & $30.9 \pm 0.88$ & $35.1 \pm 0.23$ & $33.3 \pm 0.37$ \\
\hline
\end{tabular}

Statistical analysis was performed for each combination of two values*2

[forehead $60 \mathrm{~min}$. ] : $15^{\circ} \mathrm{C} 0 \mathrm{~m} / \mathrm{s} \gg 2.0 \mathrm{~m} / \mathrm{s}, 25^{\circ} \mathrm{C} 0 \mathrm{~m} / \mathrm{s} \gg 2.0 \mathrm{~m} / \mathrm{s}, 30^{\circ} \mathrm{C} 0 \mathrm{~m} / \mathrm{s} \fallingdotseq 2.0 \mathrm{~m} / \mathrm{s}$

[cheek 60min.] : $15^{\circ} \mathrm{C} 0 \mathrm{~m} / \mathrm{s} \gg 2.0 \mathrm{~m} / \mathrm{s}, 25^{\circ} \mathrm{C} 0 \mathrm{~m} / \mathrm{s} \gg 2.0 \mathrm{~m} / \mathrm{s}, 30^{\circ} \mathrm{C} 0 \mathrm{~m} / \mathrm{s} \fallingdotseq 2.0 \mathrm{~m} / \mathrm{s}$

[nose $60 \mathrm{~min}.] \quad: 15^{\circ} \mathrm{C} 0 \mathrm{~m} / \mathrm{s} \gg 2.0 \mathrm{~m} / \mathrm{s}, 25^{\circ} \mathrm{C} 0 \mathrm{~m} / \mathrm{s} \gg 2.0 \mathrm{~m} / \mathrm{s}, 30^{\circ} \mathrm{C} 0 \mathrm{~m} / \mathrm{s} \fallingdotseq 2.0 \mathrm{~m} / \mathrm{s}$

[chin $60 \mathrm{~min}.] \quad: 15^{\circ} \mathrm{C} 0 \mathrm{~m} / \mathrm{s} \gg 2.0 \mathrm{~m} / \mathrm{s}, 25^{\circ} \mathrm{C} 0 \mathrm{~m} / \mathrm{s} \gg 2.0 \mathrm{~m} / \mathrm{s}, 30^{\circ} \mathrm{C} 0 \mathrm{~m} / \mathrm{s} \fallingdotseq 2.0 \mathrm{~m} / \mathrm{s}$

$*_{1}$ : Mean \pm S. D.

$*_{2}:$ t-test山»: $\mathrm{P}<0.01, \fallingdotseq$ not significant 
て最も気流の影響が大きく，頓部に括いては， $5.9^{\circ} \mathrm{C}$ の低下があった。気温 $30^{\circ} \mathrm{C}$ に打いては, 他の気温条件と比較し, 著しい低下は認められな かった。額, 鼻, 顎に执いても同様の傾向がみら れたが，特に鼻，顎に执いては，低温下での気流 の影響が大きかった。

\section{2 角層水分含有量}

気流暴露により, 角層水分含有量の低下がみら れた (Table-6)。気流 $2.0 \mathrm{~m} / \mathrm{s}$ 60分暴露では約 $10 \mu \mho の$ 低下があり，その他の気流速度に沶いて も同様に 2 から $10 \mu ひ の$ 低下があった。しかし， 有気流間に打いては有意な差は認められず，気流 速度とその低下の程度とに相関性は認められなか った。

各気温条件下に打いても気流暴露により角層水 分含有量は低下し (Table-7), 特に $25^{\circ} \mathrm{C}$ に特い ては気流の影響が大きかった。しかし，気温 15
${ }^{\circ} \mathrm{C}$ 及び $30^{\circ} \mathrm{C}$ の $0 \mathrm{~m} / \mathrm{s}$ と $2.0 \mathrm{~m} / \mathrm{s}$ 間では有意な 差は認められなかった。

\section{3 回復皮脂量}

異なった気流速度に和ける回復皮脂量の測定結 果を Table-8 に示した。気流暴露により，回復 皮脂量の低下があり, 特に $2.0 \mathrm{~m} / \mathrm{s}$ 以上では, 顕 著に低下していた。しかし， $2.0 \mathrm{~m} / \mathrm{s} ， 4.0 \mathrm{~m} / \mathrm{s}$ 間 では有意な差は認められなかった。

次に，異なった気温条件に和ける回復皮脂量の 測定結果を Table-9 に示した。どの気温条件に おいて子気流暴露により回復皮脂量が低下した。 特に気温 $25^{\circ} \mathrm{C}$ に特いては, $2.0 \mathrm{~m} / \mathrm{s}$ の気流暴露 によって有意に低下し， $0 \mathrm{~m} / \mathrm{s}$ に打ける皮脂量の 約 $2 / 3$ であった。しかし， $30^{\circ} \mathrm{C}$ では皮膚表面温 度と同様に, 気流の影響は顕著には認められず, $2.0 \mathrm{~m} / \mathrm{s}$ 暴露による減少はわずかであった。

Table-6 The changes in the hydration state $(\mu \tilde{\sigma})$ of the stratum corneum by air velocity exposure at $25^{\circ} \mathrm{C}$, each value show the difference from the value before air velocity exposure

\begin{tabular}{cccccc}
\hline $\begin{array}{c}\text { Exposed } \\
\text { time }\end{array}$ & $0 \mathrm{~m} / \mathrm{s}$ & 1.0 & 2.0 & 3.0 & 4.0 \\
\hline $30 \mathrm{~min}$. & $0.44 \pm 26.7 * 1$ & $-4.67 \pm 28.5$ & $-9.70 \pm 7.35$ & $-5.34 \pm 9.97$ & $-7.91 \pm 15.0$ \\
$60 \mathrm{~min}$. & $3.00 \pm 17.5$ & $-2.34 \pm 10.1$ & $-10.2 \pm 11.2$ & $-5.04 \pm 3.06$ & $-10.6 \pm 14.1$ \\
\hline
\end{tabular}

Statistical analysis was performed for each combination of two values*2

$0 \mathrm{~m} / \mathrm{s} \fallingdotseq 1.0 \mathrm{~m} / \mathrm{s} \fallingdotseq 3.0 \mathrm{~m} / \mathrm{s} \fallingdotseq 2.0 \mathrm{~m} / \mathrm{s} \fallingdotseq 4.0 \mathrm{~m} / \mathrm{s}$

*1: Mean \pm S. D.

(values of hydration state at $0 \mathrm{~min}$. ) - (values of hydration state at $30,60 \mathrm{~min}$.)

$*_{2}:$ t-test $\sqcup \fallingdotseq$ : not significant

Table-7 The changes of hydration state $(\mu \sigma)$ of stratum corneum of various air temperature

\begin{tabular}{cccccccc}
\hline $\begin{array}{c}\text { Exposed } \\
\text { time }\end{array}$ & \multicolumn{2}{c}{$15^{\circ} \mathrm{C}$} & \multicolumn{2}{c}{$25^{\circ} \mathrm{C}$} & \multicolumn{2}{c}{$30^{\circ} \mathrm{C}$} \\
\hline $30 \mathrm{~min}$. & $-1.06 \pm 4.60^{* 1}$ & $-7.17 \pm 8.35$ & $0.40 \pm 10.1$ & $-8.86 \pm 7.75$ & $3.89 \pm 15.5$ & $-7.26 \pm 12.1$ \\
$60 \mathrm{~min}$. & $-2.91 \pm 9.57$ & $-7.46 \pm 8.98$ & $-2.77 \pm 10.3$ & $-10.7 \pm 10.7$ & $-1.34 \pm 16.9$ & $-8.94 \pm 17.7$ \\
\hline
\end{tabular}

Statistical analysis was performed for each combination of two values*2

$\left[15^{\circ} \mathrm{C}\right]: 0 \mathrm{~m} / \mathrm{s} \fallingdotseq 2.0 \mathrm{~m} / \mathrm{s}$

$\left[25^{\circ} \mathrm{C}\right]: 0 \mathrm{~m} / \mathrm{s} \gg 2.0 \mathrm{~m} / \mathrm{s}$

$\left[30^{\circ} \mathrm{C}\right]: 0 \mathrm{~m} / \mathrm{s} \fallingdotseq 2.0 \mathrm{~m} / \mathrm{s}$

$* 1$ : Mean \pm S.D. : (hydration state at $0 \mathrm{~min}).-($ hydration state at $30,60 \mathrm{~min}$.

$*_{2}:$ t-test $\backsim \gg: \mathrm{P}<0.01, \fallingdotseq$ not significant 
Table-8 The effects of air velocity on squalene values as the replacement sebum level

\begin{tabular}{lccccc}
\hline air velocity $(\mathrm{m} / \mathrm{s})$ & 0 & 1.0 & 2.0 & 3.0 & 4.0 \\
\hline squalene $\left(\mu \mathrm{g} / \mathrm{cm}^{2}\right)$ & $5.19 \pm 2.67^{* 1}$ & $3.59 \pm 2.85$ & $2.43 \pm 1.28$ & $2.37 \pm 1.38$ & $2.16 \pm 0.99$ \\
\hline
\end{tabular}

Statistical analysis was performed for each combination of two values*2

$0 \mathrm{~m} / \mathrm{s} \fallingdotseq 1.0 \mathrm{~m} / \mathrm{s}>2.0 \mathrm{~m} / \mathrm{s} \fallingdotseq 3.0 \mathrm{~m} / \mathrm{s} \fallingdotseq 4.0 \mathrm{~m} / \mathrm{s}$

$* 1$ : Mean \pm S.D.

$*_{2}:$ t-test $>: \mathrm{P}<0.05, \fallingdotseq$ not significant

Table-9 The effects of air velocity and air temperature on squalene values

\begin{tabular}{lccccccc}
\hline air temperature $\left({ }^{\circ} \mathrm{C}\right)$ & \multicolumn{2}{c}{15} & \multicolumn{3}{c}{25} & \multicolumn{3}{c}{30} \\
air velocity $(\mathrm{m} / \mathrm{s})$ & 0 & 2.0 & 0 & 2.0 & 0 & 2.0 \\
\hline squalene $\left(\mu \mathrm{g} / \mathrm{cm}^{2}\right)$ & $3.91^{* 1}$ & 2.82 & 5.58 & 3.81 & 3.84 & 3.39 \\
& \pm 1.44 & \pm 1.11 & \pm 2.59 & \pm 1.53 & \pm 1.56 & \pm 0.87 \\
\hline
\end{tabular}

Statistical analysis was performed for each combination of two values*2

$\left[15^{\circ} \mathrm{C}\right]: 0 \mathrm{~m} / \mathrm{s} \gg 2.0 \mathrm{~m} / \mathrm{s}$

$\left[25^{\circ} \mathrm{C}\right]: 0 \mathrm{~m} / \mathrm{s} \fallingdotseq 2.0 \mathrm{~m} / \mathrm{s}$

$\left[30^{\circ} \mathrm{C}\right]: 0 \mathrm{~m} / \mathrm{s} \fallingdotseq 2.0 \mathrm{~m} / \mathrm{s}$

$* 1$ : Mean \pm S.D.

$*_{2}: \gg: \mathrm{P}<0.01, \fallingdotseq$ not significant
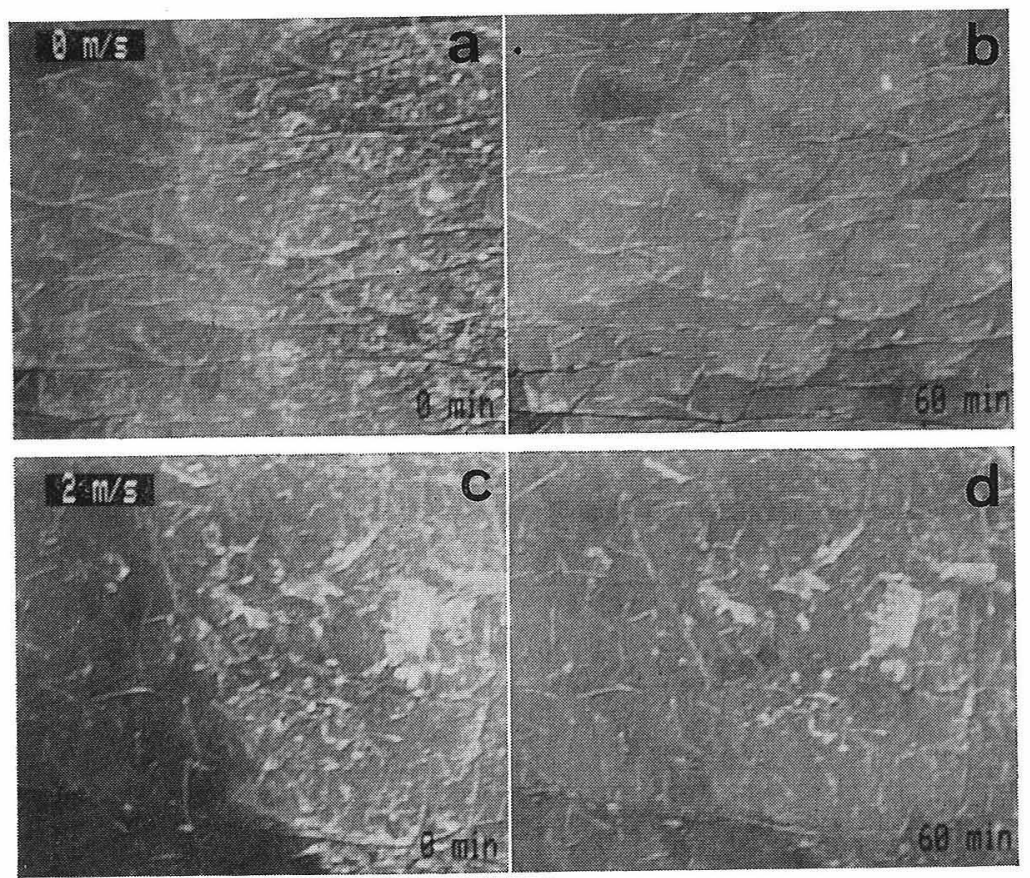

Fig.-2 Examples of skin surface extracted sebum $\mathrm{a}, \mathrm{b}$ : before and after exposure of wind $(0 \mathrm{~m} / \mathrm{s})$ for $60 \mathrm{~min}$. $c, d$ : before and after exposure of wind $(2.0 \mathrm{~m} / \mathrm{s})$ for $60 \mathrm{~min}$. 


\section{4 皮膚状態観察}

アセトンで皮脂を抽出すると，抽出した皮膚は 白色化し, 数多くの鱗屑が観察され, 抽出してい ない皮膚との差がはっきり現れた（Fig.-2)。皮脂 抽出直後及び60分後の皮膚状態のスコアの分布を Table-10 に示した。また, 皮膚の回復状態の指 標として, 各々のパネラーの皮脂抽出直後のスコ アと60分後のスコアとの差を算出し, 気流との関 係をTable-11に示した。スコアの差が低いほ ぞ，皮膚状態の回復が少ないことを示している。 これより, 気流 $0 \mathrm{~m} / \mathrm{s}$ では60分後で皮脂抽出前の 皮膚状態にまで回復していたが，気流を暴露する
と60分後に扣いても鱗屑が観察され，回復が少な い。しかし，回復の程度は気流速度間に有意な差

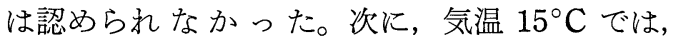
$0 \mathrm{~m} / \mathrm{s}$ でも回復は少なく, 60分後に扣いても鱗属 がみられたが，気温 $30^{\circ} \mathrm{C}$ では，気流 $2.0 \mathrm{~m} / \mathrm{s}$ 暴 露によっても皮脂抽出前の皮膚状態にまで回復し ていた。

\section{5 アンケート調査}

3.5.1 気流と心理的反応との関係

快適感は気流速度が増加するほど快適性が悪く なる傾向であった（Fig.-3）。気温条件を変えた場 合は, 気温 $15^{\circ} \mathrm{C}, 25^{\circ} \mathrm{C}$ に执いては, 気流暴露に

Table-10 Relationship between air velocity and clinical grade

\begin{tabular}{|c|c|c|c|c|c|c|c|c|c|c|}
\hline \multirow{2}{*}{$\begin{array}{l}\text { air velocity }(\mathrm{m} / \mathrm{s}) \\
\text { time }(\mathrm{min})\end{array}$} & \multicolumn{2}{|c|}{0} & \multicolumn{2}{|c|}{1.0} & \multicolumn{2}{|c|}{2.0} & \multicolumn{2}{|c|}{3.0} & \multicolumn{2}{|c|}{4.0} \\
\hline & 0 & 60 & 0 & 60 & 0 & 60 & 0 & 60 & 0 & 60 \\
\hline grade 1 & & $1^{*}$ & 1 & 3 & & & & 2 & & \\
\hline 2 & & 5 & 2 & 2 & & 2 & 3 & 1 & & 4 \\
\hline 3 & 1 & 2 & 2 & 3 & 1 & 4 & & 3 & 6 & 4 \\
\hline 4 & 7 & & 3 & & 7 & 2 & 5 & 2 & 2 & \\
\hline
\end{tabular}

* : Number of subjects

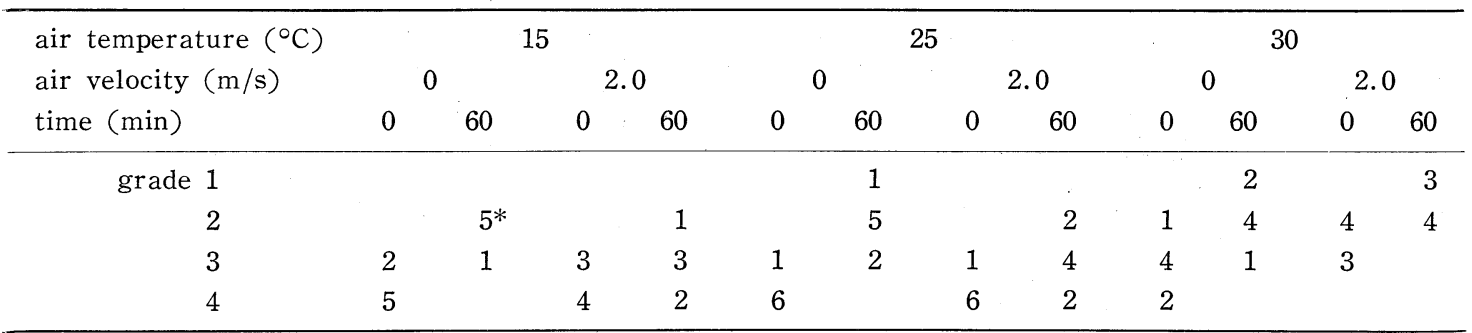

* : Number of subjects

Table-11 Relationship between air velocity and clinical grade

\begin{tabular}{|c|c|c|c|c|c|c|c|c|c|c|c|}
\hline \multirow{2}{*}{ difference*1 } & \multicolumn{5}{|c|}{$25^{\circ} \mathrm{C}$} & \multicolumn{2}{|c|}{$15^{\circ} \mathrm{C}$} & \multicolumn{2}{|c|}{25} & \multicolumn{2}{|c|}{30} \\
\hline & $0 \mathrm{~m} / \mathrm{s}$ & 1.0 & 2.0 & 3.0 & 4.0 & $0 \mathrm{~m} / \mathrm{s}$ & 2.0 & 0 & 2.0 & 0 & 2.0 \\
\hline 4 & & & & & & & & & & & \\
\hline 3 & $1 *_{2}$ & & & & & & & 1 & & 1 & \\
\hline 2 & 5 & 1 & 1 & 1 & 1 & 2 & & 5 & 1 & 2 & 1 \\
\hline 1 & 2 & 5 & 4 & 2 & 5 & 4 & 3 & 2 & 5 & 3 & 3 \\
\hline 0 & & 2 & 3 & 5 & 2 & & 3 & & 2 & 1 & 3 \\
\hline
\end{tabular}

$*_{1}$ : Difference in grade $=($ grade at $0 \mathrm{~min})-.($ grade at $60 \mathrm{~min}$.

The larger the value of difference, the more improvement of the skin condition.

$*_{2}$ : Number of subjects 
より不快と申告している人が多かったのに対し， 逆に $30^{\circ} \mathrm{C}$ では気流暴露により, 不快な状態から 快適な状態へと申告が変化していた。
温冷感は気流暴露により寒いという申告に变わ

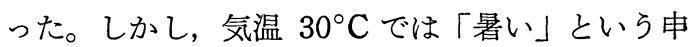
告から「ちょらどよい」といら申告に変わった
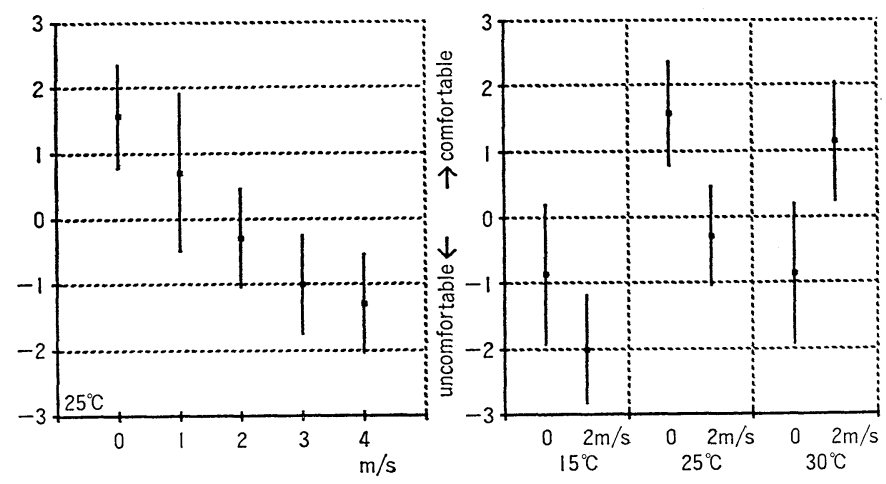

Fig.-3 Relationship between air velocity or air temperature and comfort sensation
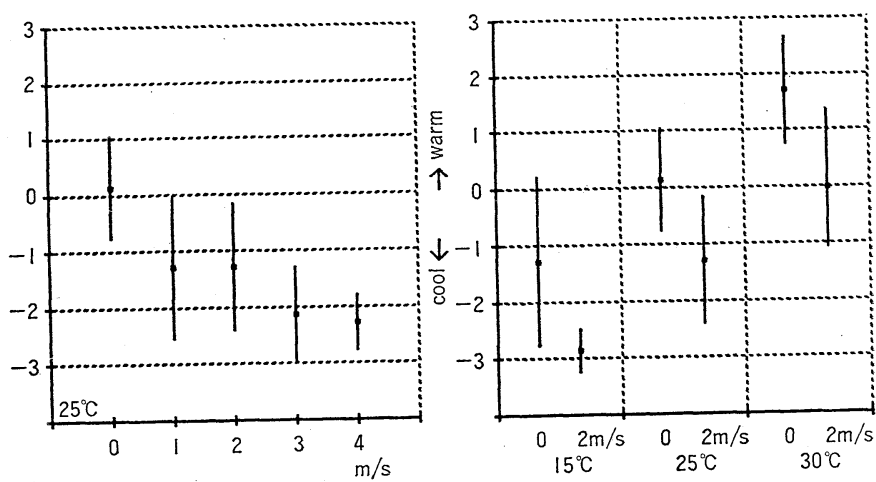

Fig. -4 Relationship between air velocity or air temperature and temperature sensation
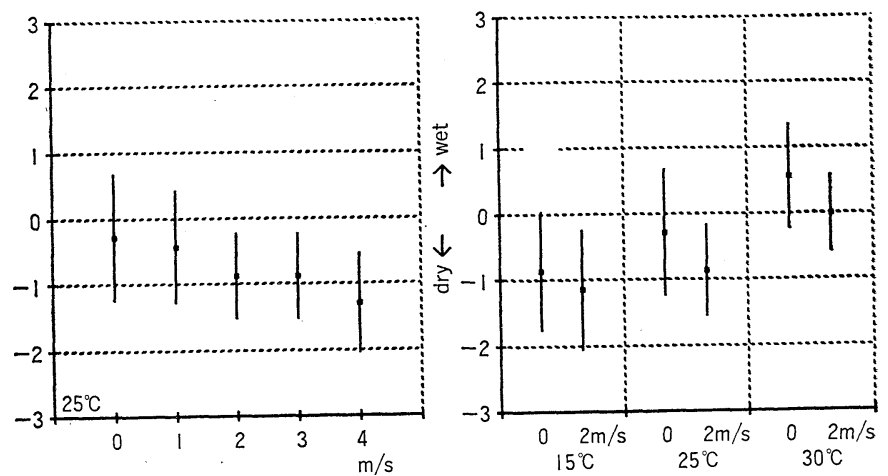

Fig. -5 Relationship between air velocity or air temperature and wetness sensation 
Table-12 Relationship between skin temperature and thermal sensation, using all values of various air velocity and air temperature

\begin{tabular}{|c|c|c|c|c|c|c|c|c|c|c|c|c|c|c|c|c|c|c|c|c|c|}
\hline \multirow{2}{*}{$\begin{array}{l}\text { skin } \\
\text { temperature }\end{array}$} & \multicolumn{7}{|c|}{ comfurt sensation } & \multicolumn{7}{|c|}{ temperature sensation } & \multicolumn{7}{|c|}{ wetness sensation } \\
\hline & -3 & -2 & -1 & 0 & 1 & 2 & 3 & -3 & -2 & -1 & 0 & 1 & 2 & 3 & -3 & -2 & -1 & 0 & 1 & 2 & 3 \\
\hline$\sim 25\left(^{\circ} \mathrm{C}\right)$ & $1^{*}$ & & 1 & & & & & 3 & & & & & & & & 1 & 2 & 1 & & & \\
\hline$\sim 30$ & 1 & 3 & 3 & & & & & 6 & 1 & & & & & & & 3 & 2 & 2 & & & \\
\hline$\sim 35$ & & 2 & 6 & 8 & 4 & 8 & & 3 & 3 & 5 & 9 & 5 & 1 & 2 & & 3 & 7 & 13 & 5 & & \\
\hline $40 \sim$ & & 1 & & 3 & & & & & & & & 3 & 1 & & & & 1 & 1 & 2 & & \\
\hline
\end{tabular}

*: Number of subjects

(Fig.-4)。

乾湿感は快適感, 温冷感と比較して, 気流暴露 による顕著な差は得られなかったが，気流暴露に より,やや乾いた感じを持つ傾向がみられた (Fig. -5)。

3.5 .2 皮膚生理パラメータと心理的反応との 関係

先の各気温条件, 気流速度条件の実験のデータ に基づいた皮膚表面温度と心理的反応との関係を

Table-12 に示した。

快適感申告は, 皮膚表面温度が $30^{\circ} \mathrm{C}$ 以上にな ると，「快適」という申告が増光，逆に皮膚表面 温度が $30^{\circ} \mathrm{C}$ 未満になると，「不快」側の申告の みとなり，皮膚表面温度の低下と快適性の低下が

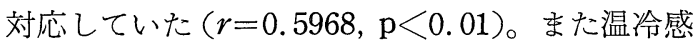
も快適感と同様に, 皮膚表面温度が $30^{\circ} \mathrm{C}$ 以下に なると「寒い」の申告が増え，それに対し，皮膚 表面温度が $34^{\circ} \mathrm{C}$ 以上になると「暑い」の申告が 増光る傾向がみられた $(r=0.6305, \mathrm{p}<0.01)$ 。一 方, 乾湿感と皮膚表面温度とに関連性は認められ なかった。

また，角層水分含有量と心理的反応との関連性 は認められなかった。回復皮脂量は温冷感に関し ては，関連性が認められた $(r=0.4133, \mathrm{p}<0.05)$ が，その他の心理的反応との関連性は認められな かった。

\section{4. 考察}

\section{1 気流発生装置について}

気流と生理的反応との関係についての報告は数 多くみられ, 被験者への気流暴露の方法も幾つか
の方法が採られている。早川らの測定では7)，換 気扇及びペーパーハニカム整流板を用いて製作し た送風装置を用い，気流を全身に暴露し測定を行 っている。また，J. LE Blank ${ }^{9)}$ らは，22.5×60 $\mathrm{cm}$ の風洞から気流を暴露させている。前者の方 法では顔面のみならず，全身への気流暴露が可能 であるということ，また後者の方法では顔面のみ しか暴露できず，また，一定の気流を暴露するた めには, 被験者と風洞との距離を $10 \mathrm{~cm}$ 程に狭め なくてはならず，そのため被験者の心理的負担が 大きくなるといらことから，今回我々は早川らが 用いている送風装置を採用した。

今回用いた気流発生装置は換気扇より起きた気 流をペーパーハニカム板により擋拌し，一定の気 流を得ることができ，顔面中心に暴露した場合の 皮膚状態への影響についての検討が可能であっ た。更に換気扇の台数を増やすことにより全身に 気流暴露が可能となるため，全身暴露での皮膚状

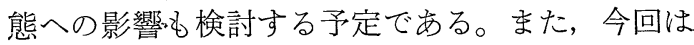
0 から $4.0 \mathrm{~m} / \mathrm{s}$ の気流条件により検討を行った が，微風及び強風の影響については, 現在検討中 である。また，実際の気象条件による影響を検討 するため, 乱流についても今後検討していく必要 があうう。

\section{2 気流の皮蜀生理の影響}

皮膚表面温度は気流暴露により顕著な低下が確 認された。これは気流速度が増すと, 空気との熱 遮断度が低下し, 皮膚表面からの不感蒸散が盛ん になり，皮膚の表面から熱が奪われやすくなった ためと考えられる。

角層水分含有量は発汗, 水分蒸散量, 環境より 
影響を受けると言われている(0)が，気流暴露によ る角層水分含有量の低下傾向が認められた。これ は気流暴露により, 皮膚の表層中からの水分が拡 散し，外気中へ失われやすくなったため角層中の 水分が低下したものと思われる。しかし, 気流速 度間には差が認められず，気流速度とその低下の 程度とに相関性が認められなかった。これは(1)気 流速度による影響が瞬時に現れるため, 測定時間 30分後に和いてはその影響が閾值に近い値として 現れている。(2)気流速度 $1 \sim 4 \mathrm{~m} / \mathrm{s}$ の気流では, 閾值に達していない。また(3)気流に対する生体側 からの防御反応が起きた。(4)今回の測定は60分と いら短いものであったため, 皮虐の急性的な反応 が現れたため等が考えられ，これについては今後 測定時間，気流速度条件等を含めさらに検討する 必要がある。

次に各気温条件下での角層水分含有量は, 気温 $25^{\circ} \mathrm{C}$ に和いて気流の影響が大きく出ているが, 気温 $15,30^{\circ} \mathrm{C}$ 条件で気流暴露しても, $0 \mathrm{~m} / \mathrm{s}$ の 時の值と有意な差は認められなかった。気温 30 ${ }^{\circ} \mathrm{C}, 2.0 \mathrm{~m} / \mathrm{s}$ 暴露での皮膚表面温度は $33^{\circ} \mathrm{C}$ から $35^{\circ} \mathrm{C}$ を示して和り, Thiele ら ${ }^{111}$ の皮膚温 $32^{\circ} \mathrm{C}$ を越えると発汗がきたされるといら報告及び, 室 温 $30^{\circ} \mathrm{C}$ 以上で皮上湿度があがるといら村上 ${ }^{12)} の$ 報告より, 発汗による水分の寄与のため, 気流を 暴露しても角層水分含有量の低下が見られなかっ

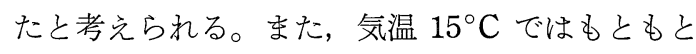
$0 \mathrm{~m} / \mathrm{s}$ での角層水分含有量が低值をとっているた め, 気流を暴露しても有意な差が認められなかっ たと思われる。尚, 水分蒸散量については, 現在 報告されている測定方法では気流による影響の検 討が困難であるため，今回は検討を行っていな い。今後は測定方法を含め, 気流と水分蒸散量と の関係を検討する必要がある。

回復皮脂量は気流 $2.0 \mathrm{~m} / \mathrm{s}$ 以上において顕著に 低下がみられたが，気流 2.0 から $4.0 \mathrm{~m} / \mathrm{s}$ 間では 有意な差は認められなかった。これは角層水分含 有量と同様, 強い気流になると, 最低限の皮脂を 保持しょらと皮脂分泌が促進される。また, 気流 に対する反応が短時間で起こり，60分暴露前に間 值に達してしまったと考えられる。今回の測定で
は，気流の影響を検出することができたが， $0 \mathrm{~m} / \mathrm{s}$ に打ける各気温条件での皮脂量の比較では有意な 差が認められなかった。気温の影響を知るために は, 回復皮脂の採取時間等, 更に検討する必要が あろら。

また，皮脂を採取するためアセトン抽出を行っ たが，数多くの鱗屑が観察され，一次的な「肌あ れ」が観察された。60分後に打いては, 皮脂の回 復により, 鱗屑がかなり減少し, 皮脂抽出前の状 態にまで回復していたが，気流を暴露すると暴露 していない時と比較して「肌あれ」の回復があま りみられなかった。このことは, 肌あれを起こし ている皮膚は, 気流から保護する必要があること を示唆している。以上のように，気流が角層水分 含有量や皮脂量に影響を及ぼすことが明らかとな った。今後は, 更に他の皮膚生理機能への影響, 或いは発汗, ホルモン等の生理学的な要因を含 め, 検討していく予定である。

\section{3 気流の心理的反応への影響}

気流暴露により, 快適感, 温冷感の申告は「不 快」及び「寒い」という申告に変化しているが, これは皮膚表面温度の顕著な低下によるものと思 われる。皮虐表面温度と心理的反応との関係をみ てみると, 皮膚表面温度が $30^{\circ} \mathrm{C}$ 以下になると, 「不快」の申告, 及び「寒い」といら申告が増え ている。つまり, 気流を加味した体感温度は環境 温度と風速により左右され, 気流が増加すると体 感温度が下がり，また，事実皮膚表面温度も低下 しているため, 温冷感や快適感の申告も「寒い」 や「不快」という申告に変化したものと思われ る。

\section{5. 総括}

今回の測定により, 気流が皮膚生理機能に影響 を及ぼすことが明らかとなった。また，その影響 の程度は, 気温条件によって異なること, そし て, 影響の程度は気流速度への依存性が低いこと が示唆された。また, 気流暴露による心理的反応 への影響もみられ, 皮膚表面温度との関連性が認 められた。

本研究を行うにあたり，有益な御助言をいただい 
た，国立公衆衛生院の都築和代先生に深謝する。

\section{参考文 献}

1) T. Abe, et al, Chem. Pharm, Bull, 28, 387 (1980)

2) 岡本暉公彦, 香粧会誌, 4, 491 (1980)

3）安部 隆, 籸技誌, 12, 17 (1978)

4) 吉国好道, 日皮会誌，95，591 (1985)

5) 井川正治, 日生気誌，16，49 (1979)

6）磯田憲生, 日本建築学会論文報告集, 229, 121 (1975)
7）早川和代，日生気誌，25，3，129（1988）

8) 小林ᄂ太郎, 空気調和衛生工学, 46, 37 (1972)

9) J. LE Blank, et al, J. Appl. Physiol., 40, 127 (1976)

10）大野盛秀, 日皮会誌, 97, 953 (1987)

11) F.A.J. Thiele, Handbuch der Haut-und Geschlechtskrankheiten. Physiologie de Haut, III, Springer-Verlag, 153 (1981)

12）村上義武, 医学研究, 30, 584 (1960)

(1992年 8 月 6 日受理)。 